\title{
PENGARUH PENGGUNAAN MEDIA BUKU CERITA TERHADAP KEMAMPUAN MEMBACA SISWA PADA PEMBELAJARAN BAHASA INDONESIA KELAS IV SD
}

\author{
Marwati, M.Basri \\ Pendidikan Guru Sekolah Dasar, Fakultas Keguruan dan Ilmu Pendidikan \\ Universitas Muhammadiyah Makassar \\ Iqramsyar34@gmail.com
}

\begin{abstract}
ABSTRAK
Masalah dalam penelitian ini yaitu Apakah ada pengaruh penggunaan media buku cerita terhadap kemampuan membaca siswa pada pembelajaran Bahasa Indonesia Kelas IV SD Inpres Tala'borong Kecamatan Bajeng Barat Kabupaten Gowa? Penelitian ini adalah penelitian eksperimen dengan desain penelitian One Group Pretest-Posttest Desain yang bertujuan untuk mengetahui apakah ada pengaruh yang signifikan terhadap kemampuan membaca siswa pada pembelajaran Bahasa Indonesia siswa yang diajar dengan menggunakan media buku cerita dan siswa sebelum perlakuan penggunaan media kelas IV SD Inpres Tala'borong Kecamatan Bajeng Barat Kabupaten Gowa, tahun ajaran 2016/2017. Populasi dalam penelitian ini adalah siswa kelas IV SD Inpres Tala'borong Kecamatan Bajeng Barat Kabupaten Gowa, dengan jumlah sampel 19 orang siswa untuk test awal (pre-test) dan test akhir (post-test). Pengolahan data hasil penelitian menggunakan dua teknik statistik, yaitu: 1) Teknik Analisis Deskriptif untuk menggambarkan kemampuan membaca siswa kelas IV SD Inpres Tala'borong Kecamatan Bajeng Barat Kabupaten Gowa, 2) Teknik Analisis Inferensial untuk menguji hipotesis penelitian. Berdasarkan analisis deskriptif didapatkan bahwa kemampuan membaca siswa pada pembelajaran Bahasa Indonesia baik siswa yang diajar dengan perlakuan penggunaan media buku cerita maupun yang diajar tidak menggunakan media buku cerita termasuk kategori tinggi, tetapi persentasi kemampuan membaca siswa yang diajar setelah perlakuan dengan menggunakan media buku cerita, pada kategori sangat tinggi lebih besar dibandingkan dengan siswa yang diajar tanpa menggunakan media buku cerita. Analisis inferensial menunjukkan bahwa terdapat perbedaan yang signifikan kemampuan membaca siswa yang diajar dengan penggunaan media buku cerita. Dari uji hipotesis dua sampel yang berpasangan didapatkan bahwa kemampuan membaca siswa pada pembelajaran Bahasa Indonesia siswa yang diajar dengan menggunakan media buku cerita kemampuan membacanya meningkatdari $61,84 \%$ menjadi $74,63 \%$ dibandingkan dengan yang diajar tanpa menggunakan media buku ceritameningkatdari 61,84\% menjadi 76,63\% pada siswa kelas IV SD Inpres Tala'borong Kecamatan Bajeng Barat Kabupaten Gowa.
\end{abstract}

Kata kunci : Media Pembelajaran; Buku Cerita; Kemampuan Membaca; Pembelajaran Bahasa Indonesia. 


\section{PENDAHULUAN}

Guna mencapai fungsi dan tujuan tersebut di atas,pemerintah menyediakan lembaga-lembaga pendidikan berupa sekolah yang terbagi kepada beberapa tingkatan, mulai dari Sekolah Dasar (SD/MI),

Sekolah

LanjutanTingkatPertama(SLTP),Sekolah Lanjutan Tingkat Atas (SLTA), sampai dengan tingkat perguruan tinggi. Di sekolah sekolah tersebut diajarkan bermacam-macam mata pelajaran dan keterampilan yang harus peserta didik kuasai demi tercapainya tujuan pendidikan di Indonesia. Salah satunya adalalah pembelajaran Bahasa Indonesia.

Bahasa berfungsi sebagai sarana menyampaikan pikiran dan perasaan dari seseorang kepada orang lain. Pengajarannya bertujuan agar seseorang terampil dalam menggunakan bahasa tertentu. Pengajaran terampil berbahasa berarti terampil menyimak, terampil membaca, terampil berbicara, dan terampil menulis dalam bahasa Indonesia yang baik dan benar.

Membaca merupakan kemampuan yang kompleks. Membaca bukan hanya kegiatan memandangi lambang-lambang tertulis semata, tetapi berupaya mengubah lambang-lambang yang dilihatnya itu menjadi lambang-lambang yang bermakna baginya yang diungkapkan dalam bahasa lisan (oral language meaning). Kemampuan ini sangat penting karena dengan membaca seseorang akan memperoleh pengetahuan yang luas tentang apa yang dibacanya.

Kemampuan membaca merupakan kemampuan yang paling dasar yang harus dikuasai oleh anak-anak sejak di usia dini terutama di tingkat dasar (SD) karena dari sinilah awal dari pembentukan keterampilan berbahasa anak-anak.

Buku adalah jendela dunia. Kalimat yang sering kita dengar dari kecil hingga dewasa. Tanpa harus berkeliling dunia, dengan membacabuku kita dapat mengetahui sesuatu yang menakjubkan tentang dunia luar. Membaca merupakan salah satu factor untuk meningkatkan kualitas hidup manusia. Membaca juga dapat menjauhkan kita dari jurang kebodohan dan menjauhkan pula dari kemiskinan.

Dalam Pembelajaran membaca hal yang terpenting adalah bagaimana menumbuhkan keinginan pada siswa untuk membaca dan meningkatkan 
pemahamnnya dalam membaca.Semakin siswa sering membaca maka semakin tinggi tingkat kemampuan membacanya. Kalau anak sudah memiliki tingkat pemahaman yang tinggi dalam membaca maka akan mudah dalam pelajaranpelajarannya di sekolah. Seringkali anak merasa bosan ketika membaca bukubuku pelajaran untuk itu kita juga harus mencari alternatif lain, yang bisa menarik misalnya dengan penggunaan media pembelajaran.

Salah satu media yang tepat merangsang siswa agar lebih tertarik untuk membaca adalah dengan menggunakan media buku cerita Karena setiap anak suka dengan cerita, selain itu media buku cerita juga merupakan media yang relatife murah dan mudah di cari.

Penggunaan media buku cerita dalam pembelajaran ini diharapkan mampu menjadi alat bantu untuk mencapai tujuan yang telah ditetapkan. Melalui penelitian eksperimen, penulis menggunakan buku cerita berupa dongeng dan legenda seperti cerita Malin Kundang, Suri Ikun dan Dua Burung, Si Rusa dan Kulomang, Nyai Roro Kidul dan Raja yang Baik Hati.

Berdasarkan identifikasi masalah yang telah dikemukakan sebelumnya, rumusan masalah dalam penelitian ini adalah "Apakah ada pengaruh penggunaan media buku cerita terhadap kemampuan membaca siswa pada pembelajaran Bahasa Indonesia Kelas IV SD Inpres Tala'borong Kecamatan Bajeng Barat Kabupaten Gowa?" Tujuan penelitian ini adalah untuk mengetahui pengaruh penggunaan media buku cerita terhadap kemampuan membaca siswa pada pembelajaran Bahasa Indonesia Kelas IV SD Inpres Tala'borong Kecamatan Bajeng Barat Kabupaten Gowa.

\section{Media Pembelajaran}

Kata media berasal dari bahasa Latin medius yang secara harfiah berarti 'tengah' atau 'pengantar', (Azhar Arsyad: 2010). Gerlach dan Ely mengatakan, "Media apabila dipahami secara garis besar adalah manusia, materi, kejadian yang membangun suatu kondisi yang membuat siswa mampu memperoleh pengetahuan, keterampilan atau sikap."Menurut Heinich dkk (1982), istilah medium adalah perantara yang mengantarkan informasi antara sumber dan penerima.

Sementara itu, Gagne dan Briggs 
(1975) secara implisit mengatakan bahwa media pembelajaran meliputi alat yang secara fisik digunakan untuk menympaikan isi materi pengajaran yang terdiri dari buku, tape recorder, kaset, video camera, video recorder, film, slide (gambar bingkai), foto, gambar, televisi, dan komputer.

Berdasarkan pendapat para ahli diatas, maka penulis dapat menyimpulkan bahwa media sering diidentikkan dengan berbagai jenis peralatan atau sarana untuk menyajikan pesan. Namun dalam hal ini yang terpenting bukanlah peralatannya, melainkan pesan belajar yang dibawa oleh media atau guru yang memanfaatkannya.

Adapun pembelajaran adalah kata yang paling tepat untuk mengartikan instruction, yaitu bagaimana mengelola agar tindakan belajar pada seseorang atau sejumlah orang secara efektif dan efisien (Ahmad Rohani: 68).

Dengan demikian, penulis dapat menyimpulkan bahwa media pembelajaran adalah sarana pembawa pesan atau wahana dari pesan yang mengundang minat anak untuk belajar yang berasal dari sumber pesan (guru) dan diteruskan kepada penerima pesan (peserta didik) supaya komunikasi lebih objektif dan tujuan pembelajaran yang telah ditetapkan dapat tercapai.

\section{Kemampuan Membaca}

Membaca adalah suatu proses yang dilakukan oleh pembaca untuk memperoleh pesan, yang hendak disampaikan oleh penulis melalui media kata-kata/bahasa tulis. Senada dengan pengertian di atas seperti yang dikutip oleh Farida Rahim (2011) bahwa membaca pada hakikatnya adalah suatu yang rumit yang melibatkan banyak hal.Oka (1983: 17) mengatakan bahwa membaca adalah proses pengolahan bahan bacaan secara kritia, kreatif dan aktif yang dilakukan dengan tujuan memperoleh pemahaman yang bersifat menyeluruh tentang bacaan itu dan penilaian terhadap keadaan, nilau, fungsi dan dampak belajar itu.

\section{METODE PENELITIAN}

Penelitian ini termasuk dalam penelitian kuantitatif dengan metode Pre Eksperimental. Desain yang digunakan dalam penelitian ini adalah The Group pretest-postest design. Dalam eksperimen ini, peneliti menerapkan penggunaan media buku cerita sebagai perlakuan yang 
diberikan kepada kelompok eksperimen dengan maksud untuk meningkatkan kemampuan membaca siswa pada pembelajaran bahasa indonesia.

Populasi dalam penelitian adalah siswa kelas IV SD Inpres Tala'borong Kecamatan Bajeng Barat Kabupaten Gowa dengan jumlah 19 orang. Dalam teknik pengambilan sampel ini peneliti menggunakan teknik sampel total (total sampling). Artinya seluruh siswa kelas IV SD Inpres Tala'borong dijadikan sampel dalam penelitian ini.Sampel penelitian siswa kelas IV SD Inpres Tala'borong. Instrumen penelitian yang akan digunakan dalam penelitian ini adalah Tes. Analisis data yang digunakan dalam penelitian ini adalah Analisis deskriptif dan Uji hipotesis.

\section{HASIL PENELITIAN DAN PEMBAHASAN}

Hasil penelitian eksperimen (sebelum perlakuan dan setelah perlakuan penggunaan media buku cerita yang telah dilakukan pada siswa kelas VI di SD Inpres Tala'borong, Kecamatan Bajeng Barat Kabupaten Gowa akan dijabarkan secara kuantitatif deskriptif. Adapun gambaran deskriptif hasil belajar bahasa Indonesia siswa diuraikan pada kelas yang diteliti (tes awal) yakni sebelum perlakuan penggunaan media buku cerita dan setelah perlakuan (tes akhir) penggunaan materi otentiksebagai berikut:

\section{Pengaruh Penggunaan Media Buku Cerita Terhadap Kemampuan Membaca Siswa pada Pembelajaran Bahasa Indonesia Siswa Kelas VI}

Dari hasil pengujian hipotesis $\mathrm{F}_{\mathrm{b}}>$ $\mathrm{F}_{\mathrm{t}}(101,4>4,45)$ sehingga $\mathrm{H}_{0}$ ditolak dan dapat disimpulkan bahwa ada pengaruh yang signifikan penerapan penggunaan media buku cerita terhadap kemampuan membaca siswa kelas IV SD Inpres Tala'borong Kab. Gowa pada pembelajaran Bahasa Indonesia.

a. Nilai Pre-test

Deskriptif kemampuan membaca siswa kelas IV SD Inpres Tala'borong Kab. Gowa, ini diperoleh tes awal (pretest) dimana siswa menunjukkan kemampuan membacanya pada pembelajaran konvensional atau pembelajaran sebelum dilakukan perlakuan penggunaan media buku cerita.

Adapun hasil gambaran deskriptif belajar Bahasa Indonesia siswa SD Inpres Tala'borong Kab. Gowa, yang diperoleh melalui tes awal (pretest) dimana 
penilaiannya diambil pada hasil tes.

Kategori nilai tertinggi yang didapatkan sebelum perlakuan penggunaan media buku cerita sebesar 80 dan nilai terendah sebesar 40 , rata-rata nilai yang diperoleh pada tes ini sebesar 61, 84\% dari 19 siswa SD Inpres Tala'borong.Selanjutnya untuk nilai statistik kemampuan membaca siswa sebelum perlakuan penggunaan media buku cerita yang dimana diukur dari hasil tes yang telah dilakukan.

Untuk kategori penilaian dapat dilihat pada tabel dibawah ini yang diukur dengan 5 tingkat penilaian, pada tes awal pada siswa kelas IV SD Inpres Tala'borong, dengan kategori "sangat rendah" sebanyak 4 murid dengan persentase 21,05\%, kategori "rendah" sebanyak 7 murid dengan persentase $36,84 \%$, kategori "sedang" sebanyak 6 murid dan kategori "tinggi" sebanyak 2 murid dengan persentase $10,53 \%$, untuk kategori "sangat tinggi" sebanyak 0 siswa yakni dengan persentase 0 persen.

Adapun nilai ketuntasan kemampuan membaca siswa kelas IV SD Inpres Kab. Gowa tahun ajaran 2016/2017. Hal ini dapat dilihat berdasarkan penilaian dari tes pembelajaran Bahasa Indonesia dikelompokkan kedalam kategori tuntas dan tidak tuntas, maka diperoleh distribusi frekuensi dan persentase ketuntasan kemampuan membaca pada tes awal (sebelum perlakuan penggunaan media buku cerita) menunjukkan kategori ketuntasan siswa kelas IV SD Inpres Tala'borong dimana siswa yang tidak tuntas sebanyak 17 dengan persentase $89,47 \%$ dan untuk siswa yang tuntas sebanyak 2 dengan persentase 10,53\%.

b. Nilai Post-test

Deskriptif hasil belajar Bahasa Indonesia siswa Kelas IV SD Inpres Tala'borong Kab. Gowa, ini diperoleh dari tes akhir (postest) dimana siswa menunjukkan hasil belajarnya setelah perlakuan penggunaan media buku cerita. Adapun gambaran hasil belajar Bahasa Indonesia siswa Kelas IVSD Inpres Tala'borong yang diperoleh melalui tes akhir (postest) dimana penilaiannya diambil juga pada hasil tes.

Kategori nilai tertinggi yang didapatkan setelah perlakuan penggunaan media buku cerita sebesar 100 dan nilai terendah sebesar 45 , ratarata nilai yang diperoleh pada tes ini sebesar 74,63\% dari 19 siswa SD Inpres 
Tala'borong.

Selanjutnya untuk nilai statistik hasil belajar Bahasa Indonesia siswa setelah perlakuan penggunaan media buku cerita yang dimana diukur dari hasil tes yang telah dilakukan.

Untuk kategori penilaian dapat dilihat pada tabel di bawah ini yang diukur dengan 5 tingkat penilaian, tes akhir pada siswa kelas IV SD Inpres Tala'borong, dengan kategori "sangat rendah" sebanyak 1 siswa dengan persentase 5,26\%, kategori "rendah" sebanyak 4 siswa dengan persentase 21,05\%, kategori "sedang" sebanyak 3 siswa dengan persentase 15,79\%, kategori "tinggi" sebanyak 6 siswa dengan persentase $31,58 \%$, serta untuk kategori "sangat tinggi" sebanyak lima siswa dengan persentase sebesar 26,32\%.

Adapun nilai ketuntasan belajar Bahasa Indonesia siswa kelas IV SD Inpres Tala'borong Kab. Gowa tahun jaran 2016/2017. Hal ini dapat dilihat berdasarkan penilaian dari tes pembelajaran Bahasa Indonesia dikelompokkan kedalam kategori tuntas dan tidak tuntas, maka diperoleh distribusi frekuensi dan persentase ketuntasan belajar Bahasa Indonesia pada test akhir (setelah perlakuan penggunaan media buku cerita) menunjukkan kategori ketuntasan siswa kelas IV SD Inpres Tala'borong dimana siswa yang tidak tuntas sebanyak 8 dengan persentase $42,11 \%$ dan siswa yang tuntas sebanyak 11 orang dengan persentase 57,89\%.

c. Nilai F $F_{\text {hitung }}$ dan $\mathrm{F}_{\text {tabel }}$

Dengan menggunakan perhitungan Regresi Linear Sederhana maka didapatkan hasil $F_{\text {hitung }}$ sebesar 101,4 dan hasil dari $F_{\text {tabel }}$ sebesar 4,45.

\section{Pengaruh Penggunaan Media Buku} Cerita Terhadap Kemampuan Membaca Siswa Pada Pembelajaran Bahasa Indonesia Kelas IV SD

Dalam pembelajaran dibutuhkan suatu media pembelajaran yang dapat membantu proses belajar mengajar. Salah satu metode yang dapat digunakan adalah penggunaan media buku cerita. Penggunaan media buku cerita merupakan media yang digunakan untuk mengetahui kemampuan membaca siswa sehingga pengaruh dari metode ini sangat signifikan terhadap kemampuan membaca siswa.

Berdasarkan hasil analisis deskriptif menunjukkan nilai rata-rata hasil belajar Bahasa Indonesia siswa yang 
diajar dengan menggunakan media buku cerita lebih baik dibandingkan dengan hasil belajar siswa sebelum perlakuan penggunaan media buku cerita.

Hal ini disebabkan siswa yang diberikan perlakuan penggunaan media buku cerita (postest) membantu siswa untuk mengetahui kemampuan membacanya, sedangkan pada saat sebelum diberi perlakuan (pretest) siswa cenderung memiliki kemampuan membaca yang kurang.

Sehingga penerapan media buku cerita dalam hal ini memberikan kesempatan terhadap siswa dalam meningkatkan kemampuan membaca sehingga pengaruh dari metode ini sangat signifikan terhadap meningkatkan kemampuan membaca siswa dan memahami isi bacaan yang ada.

Jika berorientasi pada kriteria ketuntasan minimal di SD Inpres Tala'borong pada siswa kelas IV, presentase siswa yang mencapai ketuntasan pada saat sesudah perlakuan penggunaan media buku cerita adalah $57,89 \%$ dan pada saat sebelum perlakuan media buku cerita adalah 10,53\%. Sehingga dapat dikatakan bahwa penggunaan media buku cerita lebih baik serta memberikan pengaruh yang sangat signifikan pada kemampuan membaca siswa pada pembelajaran Bahasa Indonesia kelas IV SD Inpres Tala'borong. Nilai rata-rata hasil belajar Bahasa Indonesia siswa menurut interval taksiran rata-rata pada saat sebelum perlakuan penggunaan media buku cerita (pretest) adalah 61,84\% . Sedangkan pada saat sesudah perlakuan (postest) yaitu 74,63\%. Hal ini menunjukkan bahwa jika setiap pembelajaran diberlakukan penggunaan media buku cerita, nilai ratarata siswa lebih tinggi.

Dari fakta empiris diatas, mengindikasikan bahwa nilai rata-rata kemampuan membaca siswa pada pembelajaran Bahasa Indonesia siswa kelas IV SD Inpres Tala'borong memberikan informasi kuantitatif mengenai tingkat kemampuan membaca siswa setelah perlakuan penggunaan media buku cerita.

Dengan demikian, dapatlah dikemukakan bahwa pembelajaran Bahasa Indonesia dengan menggunakan media buku cerita merupakan salah satu metode pembelajaran alternatif yang dapat digunakan untuk meningkatkan kemampuan membaca siswa pada kelas 
IV SD Inpres Kab. Gowa.

Pada bagian ini akan diuraikan hasil yang ditemukan dalam penelitian dalam penelitian . hasil yang dimaksudkan yaitu kesimpulan yang diambil berdasarkan data yang terkumpul dan analisis data yang telah dilakukan.

Hasil analisis

data memperlihatkan bahwa dari 22 jumlah murid yang menjadi sampel penelitian, maka diperoleh nilai hitung $r_{\text {hitung }}$ sebesar 0,465 .

Untuk mengetahui nilai pengujian hipoteis penelitian maka nilai $\mathrm{r}_{\text {hitung }}$ dihubungkan dengan $r_{\text {tabel }}$ pada taraf signifikan 5\% kriteria pengujian hipotesis adalah sebagai berikut:

1. Jika nilai $r_{\text {hitung }}$ lebih besar dari pada $r_{\text {tabel }}$ maka hipotesis diterima.

2. Jika nilai $\mathrm{r}_{\text {hitung }}$ lebih kecil dari pada nilai $\mathrm{r}_{\text {tabel }}$ maka hipotesis ditolak.

3. Nilai $r_{\text {tabel }}$ yang digunakan sebagai pembanding yaitu diketahui dengan cara mencari nilai yang berada pada taraf signifikan $5 \%$ dan $\mathrm{N}=22$

Pengujian analisis data menunjukkan nilai $r_{\text {hitung }}$ sebesar 0,465 jumlah korelasi merupakan hasil dari analissis product moment yang diambil dari hasil tes melalui pengajaran mengunakan minat baca dan prestasi belajarsedangkan nilai $r_{\text {tabel }}$ sebesar 0,381 hal ini dapat diperoleh dapat taraf signifikan 5\% dengan N=22 Hasil olahan data dari nilai penerapan minat baca dengan prestasi belajar murid, membuktiakan bahwa nilai analisis $r_{h i t u n g}$ lebih besar dari pada nilai $r_{\text {tabel maka }}$ hipotesis yang diajukan dalam penelitian ini diterima dan terdapat hubungan yang signifikan anatara penerapan minat baca dan prestasi belajar murid SDN Minasa Upa Kecamatan Rappocini Kota Makassar.

\section{KESIMPULAN DAN SARAN}

Berdasarkan hasil penelitian maka dapat disimpulkan bahwa Rata-rata nilai kemampuan membaca pada pembelajaran Bahasa Indonesia siswa kelas IV SD Inpres Tala'borong Kecamatan Bajeng Barat Kabupaten Gowa, dengan menggunakan media buku cerita terdapat pada kategori sangat tinggi serta lebih besar dibandingkan dengan siswa yang sebelumnya diajar tidak menggunakan media buku cerita. Penggunaan media buku cerita sangat berpengaruh signifikan terhadap kemampuan siswa pada pembelajaran membaca Bahasa Indonesia 
dibandingkan siswa yang sebelumnya diajar dengan tidak menggunakan media buku cerita. Berdasarkan hasil analisis dari penelitian ini, hasil belajar Bahasa Indonesia siswa yang diajar dengan menggunakan media buku cerita lebih tinggi dibandingkan yang diajar tanpa menggunakan media buku cerita. Dengan demikian penggunaan media buku cerita merupakan salah satu metode pembelajaran yang sangat berperan dalam meningkatkan kemampuan membaca siswa pada pembelajaran Bahasa Indonesia siswa kelas IV SD Inpres Tala'borong Kecamatan Bajeng Barat Kabupaten Gowa. Dari hasil pengujian hipotesis $F_{b}>F_{t}(101,4>4,45)$ sehingga $\mathrm{H}_{0}$ ditolak dan dapat disimpulkan bahwa ada pengaruh yang signifikan penerapan penggunaan media buku cerita terhadap kemampuan membaca siswa kelas 1V SD Inpres Tala'borong kab.Gowa pada pembelajaran Bahasa Indonesia.

Berdasarkan kesimpulan di atas, maka penulis memberikan beberapa saran sebagai berikut (1) Dalam kegiatan belajar mengajar guru diharapkan menjadikan penggunaan media buku cerita sebagai suatu alternatif dalam mata pelajaran Bahasa Indonesia untuk meningkatkan kemampuan membaca siswa. (2) Diadakan usaha untuk meningkatkan kesadaran siswa tentang perlunya kemampuan membaca, karena apabila kemampuan membaca ini telah tertanam dalam diri maka kemungkinan anak lebih mudah mengerti maksud, isi dan tujuan pembelajaran. (3) Kepada guru bidang studi diharapkan untuk lebih memotivasi siswa dengan menciptakan pembelajaran yang kreatif yang dapat menimbulkan minat belajar siswa, dan seorang guru juga harus meningkat kualitas diri dengan memberikan teladan dan bimbingan kepada para siswa. (4) Kepada pihak sekolah agar lebih memperhatikan keluhan dari guru-guru dan sekolah seperti sumber atau alat belajar yang dibutuhkan dalam proses pembelajaran. (5) Untuk para siswa agar lebih aktif dalam pembelajaran agar tercipta interaksi antara guru dan siswa, sehingga dapat menciptakan suasana belajar yang menyenangkan. (6) Kepada penulis dengan hasil penelitian ini dapat membantu para peneliti selanjutnya untuk berpacu mencari hal-hal yang baru untuk diteliti dan untuk pengembangan diri pribadi untuk masa yang akan datang. 


\section{DAFTAR PUSTAKA}

Ahmad Rohani. 2010. Pengelolaan Pengajaran. Jakarta: Rineka Cipta.

Anas Sudijono. 2011. Pengantar Evaluasi Pendidikan. Jakarta: PT Raja Grafindo Persada.

Arief S., dkk. 2012. Media Pendidikan. Jakarta: PT Raja Grafindo Persada.

Arikunto. 2012. Prosedur Penelitian. Jakarta: Rineka Cipta.

Azhar Arsyad. 2013. Media pembelajaran. Jakarta: PT Raja Grafindo Persada.

Burn. 2009. Teaching Reading in Today's Elementary Schools. Boston: Houghton Mifflin Company.

Djago Tarigan. 1990. Pendidikan Bahasa Indonesia. Jakarta: Universitas Terbuka.

Farida Rahim. 2011. Pengajaran Membaca di Sekolah Dasar. Jakarta: Bumi Aksara.

Gerlach dan Ely.1971. Media pembelajaran. United States of America: Sage Publication.
Gujarati. 2006. Metode Penelitian. Yogyakarta: PT Raja Grafindo Persada

Hasnida. 2015. Media Pembelajaran Kreatif. Jakarta: PT Luxima Metro Media.

Henry Guntur, Tarigan. 1987. Membaca Ekspresif. Bandung: Angkasa.

Henry Guntur, Tarigan. 1997. Membaca Sebagai Suatu Keterampilan Berbahasa. Bandung: Aksara.

Nurhadi. 2005. Membaca cepat dan efektif. Bandung: Sinar Baru Algesindo.

Oka. 1983. Pengantar Membaca dan Pengajarannya. Surabaya: Usaha Nasional.

Sudjana. 1990. Media Pembelajaran. Bandung: Sinar Baru.

Sumanto. 2014. Statistika Deskriptif. Yogyakarta : CAPS.

Supardi. 2014. Aplikasi Statistika Dalam Penelitian. Jakarta: Change Publication. 